\title{
EFFECT OF VARIOUS ANIONS ON THE STEPWISE MELTING OF PLASMID DNA
}

\author{
KAZUKO NUNOMURA, EIICHI OHTSUBO, AND YOSHIMI MAEDA ${ }^{1, *}$ \\ Institute of Molecular and Cellular Biosciences, The University of Tokyo, \\ Bunkyo-ku, Tokyo 113, Japan \\ ${ }^{1}$ College of Science and Engineering, Iwaki Meisei University, \\ Iwaki 970, Japan
}

(Received August 23, 1993)

Differential scanning calorimetry (DSC) was carried out for the study on the effect of various anions on the melting of plasmid pJL3-TB5 DNA $\left(5,277\right.$ base pairs in length). In the presence of halide ions such as $\mathrm{Cl}^{-}$, $\mathrm{Br}^{-}$, or $\mathrm{I}^{-}$in citrate buffer solutions, seven separate peaks caused by the stepwise melting of the DNA molecule were found in the DSC curve. Similar profile of the DSC curve was also found in the presence of $\mathrm{SCN}^{-}$. Such a characteristic melting profile was not observed, when some other buffer solutions such as phosphate, borate, and acetate buffers were used. These ions affected significantly the melting profile of DNA; the height of the peaks seen in the high temperature range decreased and broadened. The presence of the anions such as $\mathrm{NO}_{3}{ }^{-}, \mathrm{ClO}_{4}{ }^{-}, \mathrm{SO}_{4}{ }^{2-}$, and $\mathrm{IO}_{3}{ }^{-}$instead of $\mathrm{Cl}^{-}$in the saline-sodium citrate (SSC) buffer solution also affected the DSC curves in the high temperature range in the similar manner to phosphate, borate, and acetate buffers. These results indicate that the type of anions in the solution as well as that of cations is very important for the melting of DNA. Since anions are known to alter the structure of water, it is suggested that these results are closely related to alteration of the structure of water caused by the interaction between anions and water, rather than the direct interaction between anions and DNA. The borate buffer solutions also showed not only clearly separated peaks, but also excellent reversibility for the melting of the DNA.

Stepwise transition of double-stranded DNA to single-stranded DNA which occurs during the process of temperature rising can be detected by differential scanning calorimetry (DSC). The DSC curve of plasmid DNA agrees well with the

* Address reprint requests to: Dr. Yoshimi Maeda, College of Science and Engineering, Iwaki Meisei University, Iino, Chuohdai, Iwaki 970, Japan. 
melting curve obtained theoretically from the entire nucleotide sequence of the DNA and it is therefore possible to assign the peaks of DSC curve to the particular regions in the nucleotide sequence $(5,8)$. This has made it possible to study on the interaction of reagents with DNA and to know their influence on the melting of the particular sequence of DNA $(6,7,16)$.

The stability of double-stranded DNA depends on the ambient conditions, and many researches have been carried out relating to the factors that may affect the stability of double-stranded DNA. The workers have mainly been concerned with the effect of cations that stabilize the double-strand of DNA by screening effect for repulsion between negatively charged phosphates and coordination to specific sites on the base pairs $(1,15)$. In contrast to the effect of cations, there have been only a few reports about the effect of anions on the stability of the double-stranded DNA $(2-4,9,14)$. In our present study, DSC curves show evidently that the helix-coil transition of DNA is affected by the presence of certain anions. Unlike cations, anions do not seem to interact directly with the phosphate, deoxyribose or bases of DNA. Therefore, it is suggested that the observed effects of anions are due to the structural change of water caused by solute-solvent interaction.

\section{MATERIALS AND METHODS}

DNA. The plasmid DNA used in this study was pJL3-TB5 $(5,277$ base pairs in length; $49.5 \%$ in $\mathrm{G}+\mathrm{C}$ content). This is composed of the entire sequence of transposon Tn9 flanked by two copies of insertion sequence IS1 and parts of each sequence from plasmid pMB8 and transposon $\operatorname{Tn} 3$ (5). The distribution of $\mathrm{G}+\mathrm{C}$ content of pJL3-TB5 along the DNA molecule ( $\mathrm{G}+\mathrm{C}$ distribution map) was shown in the previous paper (5). The covalently closed circular (ccc) DNA was purified according to the method described by Ohtsubo et al. (10), and linearized by digestion with EcoRI. The plasmid DNA was treated successively with phenol and ethyl ether and precipitated with ethanol in order to concentrate DNA. The pellet was rinsed twice with $70 \%(\mathrm{v} / \mathrm{v})$ of cold ethanol and dried under vacuum. The plasmid sample thus obtained was redissolved in various buffer solutions including saline-sodium citrate (SSC) buffer $(0.15 \mathrm{M} \mathrm{NaCl}$ and $0.015 \mathrm{M} \mathrm{Na}$ citrate, $\mathrm{pH} 7.0)$. The concentration of DNA used for DSC measurement was $0.5 \%(\mathrm{w} / \mathrm{v})$.

DSC. A heat-flux type of differential scanning calorimeter SSC 560U (Seiko Instruments \& Electronics Ltd., Tokyo, Japan) was used. The total volume of 60 $\mu \mathrm{l}$ of samples was put in a sample vessel made of silver and tightly sealed. The operation of temperature scanning was carried out at $0.5^{\circ} \mathrm{C} \mathrm{min}{ }^{-1}$. The procedure of acquisition of data from the calorimeter and all of the subsequent data processing have been described previously $(5,6,8)$.

Chemicals. Inorganic salts, citric acid and acetic acid were specially prepared grade materials obtained commercially and were used without further purification. The $\mathrm{pH}$ and cation concentration of all of the salt solutions used were adjusted to 7.0 and $0.195 \mathrm{M}$, respectively, except for borate buffer; i.e., borate buffer A: $0.65 \mathrm{M}$ 
$\mathrm{H}_{3} \mathrm{BO}_{3}, 0.098 \mathrm{M} \mathrm{Na}_{2} \mathrm{CO}_{3}$, pH 7.14; borate buffer B: $0.175 \mathrm{M} \mathrm{KCl}, 0.017 \mathrm{M} \mathrm{H}_{3} \mathrm{BO}_{3}$, $0.01 \mathrm{M} \mathrm{Na}_{2} \mathrm{CO}_{3}, \mathrm{pH}$ 9.1. In the case of borate buffer $\mathrm{B}$ the concentration of $\mathrm{Na}^{+}+$ $\mathrm{K}^{+}$was adjusted to $0.195 \mathrm{M}$ which is the concentration of the cation in $1 \times \mathrm{SSC}$ buffer solution.

\section{RESULTS AND DISCUSSION}

DSC curves of DNA melting in various buffer solutions

Figure 1 shows the DSC curves of the melting of pJL3-TB5 DNA in various solutions such as citrate (SSC), phosphate, borate, and acetate buffers. In the SSC buffer solution, the DSC curve of pJL3-TB5 DNA demonstrated seven endothermic peaks numbered 1 to 7 in the order of increasing temperature (Fig. 1a) as already shown in our previous paper $(5,6)$. Seven separate peaks also appeared in the DSC curves for the other buffer solutions used, but melting positions and the overall profile of the DSC curves are different from those of SSC. Particularly peak 7 seen in the high temperature range of the DSC curves varied remarkably. Each of the

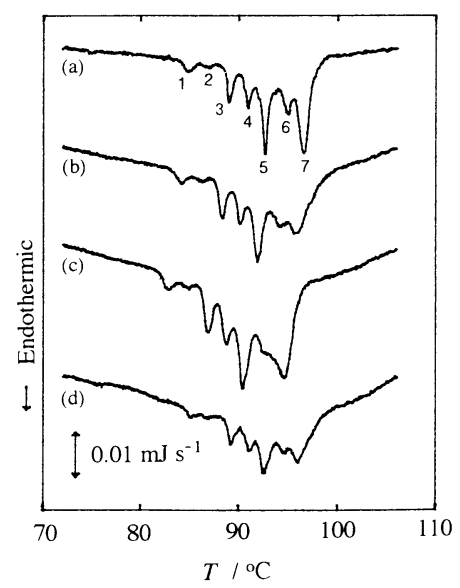

Fig. 1

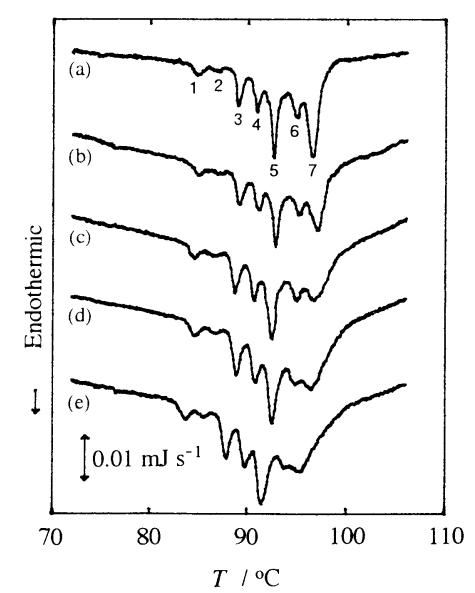

Fig. 2

Fig. 1. The DSC curves of the melting of pJL3-TB5 DNA in various buffer solutions.

About $60 \mathrm{mg}$ of the solution containing $300 \mu \mathrm{g}$ of DNA was packed in a calorimeter vessel and tightly sealed. The operation of temperature scanning was carried out at $0.5^{\circ} \mathrm{C} \mathrm{min}^{-1}$. (a) SSC buffer: $0.15 \mathrm{M} \mathrm{NaCl}+0.015 \mathrm{M} \mathrm{Na}$ citrate; (b) phosphate buffer: $\mathrm{Na}_{2} \mathrm{HPO}_{4}+\mathrm{KH}_{2} \mathrm{PO}_{4}$; (c) borate buffer $\mathrm{A}: \mathrm{Na}_{2} \mathrm{CO}_{3}+\mathrm{H}_{3} \mathrm{BO}_{3}$; (d) acetate buffer: $\mathrm{CH}_{3} \mathrm{COONa}+\mathrm{CH}_{3} \mathrm{COOH}$.

Fig. 2. Effect of the concentration of $\mathrm{Cl}^{-}$on the DSC curve of the melting of pJL3-TB5 DNA.

$0.015 \mathrm{M} \mathrm{Na}_{3}$ citrate + (a) $0.15 \mathrm{M} \mathrm{NaCl}$; (b) $0.075 \mathrm{M} \mathrm{NaCl}$; (c) $0.015 \mathrm{M} \mathrm{NaCl}$; (d) $0.003 \mathrm{M} \mathrm{NaCl}$; (e) $0 \mathrm{M} \mathrm{NaCl}$. The concentration of $\mathrm{Na}^{+}$in each solution was adjusted to $0.195 \mathrm{M}$ by adding $\mathrm{NaNO}_{3}$. See Fig. 1 for other information. 
buffer solutions here used are different in anion constitution, although the concentration of cations is the same as that of $1 \times \mathrm{SSC}\left(0.195 \mathrm{M}\right.$ of $\left.\mathrm{Na}^{+}+\mathrm{K}^{+}\right)$. Therefore, the variation in the peaks in the higher temperature range may be due to the effect of anions in the solution.

The effect of $\mathrm{Cl}^{-}$on the DSC curve was examined by varying concentration of $\mathrm{Cl}^{-}$(Fig. 2). The concentration of $\mathrm{Cl}^{-}$in $\mathrm{SSC}$ buffer was varied by removing $\mathrm{NaCl}$ and instead adding $\mathrm{NaNO}_{3}$ to hold the total anions at the constant concentration $\left(\mathrm{Cl}^{-}+\mathrm{NO}_{3}{ }^{-}+\right.$citrate ions $\left.=0.165 \mathrm{M}\right)$. As expected, a well-defined change is observed in peak 7 depending on the $\mathrm{Cl}^{-}$concentration; that is, as the concentration of $\mathrm{Cl}^{-}$in the solution decreased from $0.15 \mathrm{M}$ to $0 \mathrm{M}$, the height of peak 7 decreased and broadened. As mentioned above, it is generally thought that, in the SSC solution containing $\mathrm{NaCl}, \mathrm{Na}^{+}$is required as counter-cation to screen DNA phosphate anions for the stability of double-stranded DNA. However, the results obtained here indicate that $\mathrm{Cl}^{-}$has also an important role on the stability of double-stranded DNA.

The DSC curve examined in the $2 \times \mathrm{SSC}$ or $1 / 2 \times \mathrm{SSC}$ solution (Fig. $3 \mathrm{a}$ and $\mathrm{c}$ ) was similar to the DSC curve examined in the $1 \times$ SSC solution (Fig. $3 b$ ) in its overall profile, but the melting temperatures of the peaks shifted to a high or low temperature range depending on the concentration of SSC. It seems reasonable to suppose that the $\mathrm{Na}^{+}$ions screening the negatively-charged phosphate groups of DNA as a counter-cation may alter the relative rigidity of the double-stranded helixes. We can observe here again the decrease and broadening of peak 7 with decreasing concentration of SSC, probably due to the effect of $\mathrm{Cl}^{-}$.

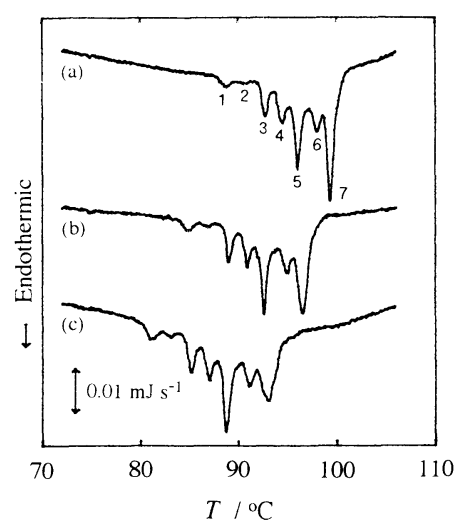

Fig. 3. Effect of SSC concentration on the stepwise melting of pJL3-TB5 DNA monitored by DSC.

SSC concentration of each solution is as follows: (a) $2 \times$ SSC; (b) $1 \times$ SSC; (c) $1 / 2 \times$ SSC. See Fig. 1 for other information. 
Effect of other halide ions on the DSC curve of DNA melting

As mentioned above, $\mathrm{Cl}^{-}$affects significantly the peaks seen in the high temperature range in the DSC curve of DNA. The effect of other halide ions such as $\mathrm{F}^{-}, \mathrm{Br}^{-}$, and $\mathrm{I}^{-}$was also examined. Figure 4 shows the DSC curves obtained in the solutions where $\mathrm{NaCl}$ in the $\mathrm{SSC}$ solution was replaced by $\mathrm{NaF}, \mathrm{NaBr}$, or $\mathrm{NaI}$ (Fig. 4a, c, d, respectively). There are seven separate peaks in the DSC curves for the halide ions except for $\mathrm{NaF}$ without height decrease and broadening of peak 7 , but all the peak positions were shifted slightly to the lower temperature region according to their magnitude of ionic radii. The results indicate that the interaction of $\mathrm{Cl}^{-}, \mathrm{Br}^{-}$and $\mathrm{I}^{-}$with DNA is similar to each other. The DSC curve in NaF solution, however, shows large alteration compared with other halide ions; that is, all the peaks of the DSC curve broadened. $\mathrm{F}^{-}$is the smallest in its ionic radius among the halide ions and has a well-known specificity in the strong interaction with water. Therefore, the DSC curve observed with NaF may reflect changes in the local structure of DNA through the strong influence of $\mathrm{F}^{-}$on the structure of water which surrounds the DNA.

We examined gel electrophoretic mobility of DNA treated with NaF solution in the same manner as for DSC. However, the direct interaction of $\mathrm{F}^{-}$with the DNA could not be observed as a migration anomaly on an agarose gel (data not shown), suggesting that $\mathrm{F}^{-}$may influence the DNA through the interaction with solvent.

Effect of other anions on the DSC curve of DNA melting

The ionic interaction with DNA has been reported by Hamaguchi and Geidu-

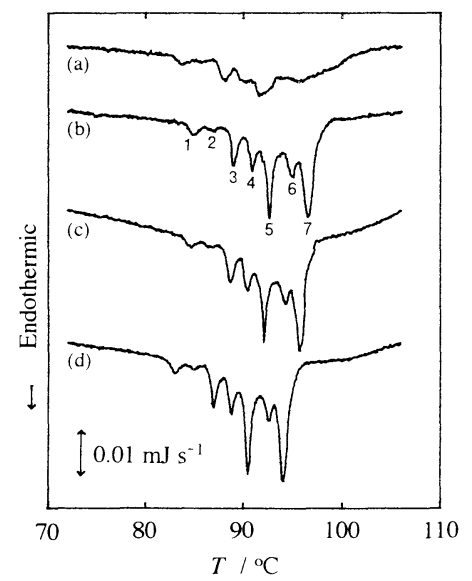

Fig. 4. Effect of halide ions on the DSC curves of the melting of pJL3-TB5 DNA.

$\mathrm{NaCl}$ in the SSC buffer solution (b) was replaced by $\mathrm{NaF}$ (a), $\mathrm{NaBr}$ (c), and $\mathrm{NaI}$ (d). See Fig. 1 for other information. 
schek (2) by use of optical methods and viscosity measurement, indicating that the anions at a high concentration have a powerful denaturing effect on DNA. They concluded that the denaturing action of anions is due to its effect on the structure of water. As to the anion-water interaction, there is a strong correlation between the structure of water and the certain ions, so-called chaotropic ions: $\mathrm{SCN}^{-}, \mathrm{I}^{-}$, $\mathrm{ClO}_{4}{ }^{-}, \mathrm{NO}_{3}{ }^{-}, \mathrm{Br}^{-}, \mathrm{Cl}^{-}, \mathrm{CH}_{3} \mathrm{COO}^{-}, \mathrm{F}^{-}$, and $\mathrm{SO}_{4}{ }^{2-}$. These chaotropic ions are known as structure breaking ions for liquid water. Note that halide ions used here belong to the chaotropic ions. We examined some other chaotropic ions with a hope of a similar effect on the melting curve of DNA. We also examined $\mathrm{IO}_{3}{ }^{-}$ions, although it is not listed in the above chaotropic ions.

Figure 5 shows the DSC curves of the melting of pJL3-TB5 DNA in the presence of $\mathrm{SCN}^{-}, \mathrm{ClO}_{4}{ }^{-}, \mathrm{SO}_{4}{ }^{2-}$, or $\mathrm{IO}_{3}{ }^{-}$ions. $\mathrm{NaCl}$ in the $\mathrm{SSC}$ solution (Fig. 5a) was replaced by $\mathrm{NaSCN}_{2} \mathrm{NaClO}_{4}, \mathrm{Na}_{2} \mathrm{SO}_{4}$, or $\mathrm{NaIO}_{3}$ (Fig. 5b, c, d, e, respectively). The profiles of the DSC curves in the presence of $\mathrm{ClO}_{4}{ }^{-}, \mathrm{SO}_{4}{ }^{2-}$, and $\mathrm{IO}_{3}{ }^{-}$almost resulted in the disappearance or remarkable broadening of peaks 6 and 7, but in the presence of $\mathrm{SCN}^{-}$these peaks were as sharp as in the presence of halide ions except for $\mathbf{F}^{-}$. This result indicates that those ions may not give the same effect on the heat transition of DNA, even though they belong to the category of chaotropic ions.

\section{Reversibility of DNA melting}

Reversibility of the melting of pJL3-TB5 DNA was examined by the repeat of heating and cooling in the calorimeter under the various ionic conditions mentioned above. The least hysteresis was observed in the borate buffers among those ionic solutions, as shown in Fig. 6 in comparison with SSC buffer. In particular, it is interesting that the sharpness of almost all the peaks including the peaks in the high

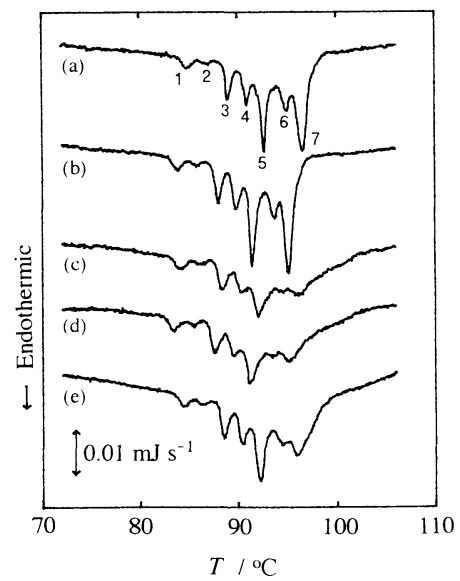

Fig. 5. Effect of other chaotropic ions on the melting of pJL3-TB5 DNA.

$\mathrm{NaCl}$ in the SSC buffer solution (a) was replaced by $\mathrm{NaSCN}$ (b), $\mathrm{NaClO}_{4}$ (c), $\mathrm{Na}_{2} \mathrm{SO}_{4}(\mathrm{~d})$, and $\mathrm{NaIO}_{3}$ (e). See Fig. 1 for other information. 

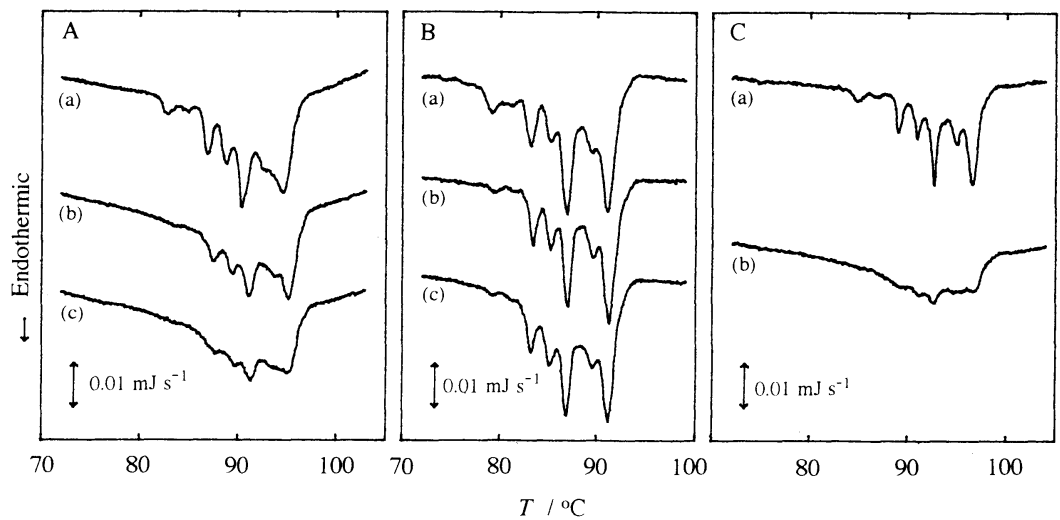

Fig. 6. Reversibility of DSC curve of the melting of pJL3-TB5 DNA in borate buffers.

Panel A shows the repeat of heating in borate buffer A: (a) 1st heating; (b) 2nd heating after cooling; (c) 3rd heating after 2nd heating and cooling. Panel B shows the repeat of heating in borate buffer B: (a) 1st heating; (b) 2nd heating after cooling; (c) 3rd heating after 2 nd heating and cooling. Panel $\mathrm{C}$ shows the repeat of heating in $1 \times$ SSC buffer: (a) 1st heating; (b) 2nd heating after cooling. See Fig. 1 for other information.

temperature range can be seen with very small hysteresis during the repeat processes of heating and cooling in the borate buffers B (Fig. 6B). The sharpness of the peaks in the high temperature range is probably due to the presence of $\mathrm{Cl}^{-}$ in the buffer solution.

It was shown that the DSC curves of pJL3-TB5 DNA were affected significantly by the type of anions which are present in the DNA solutions. These anions are classified into two groups according to the effect on DNA melting; the first group of anions are $\mathrm{Cl}^{-}, \mathrm{Br}^{-}, \mathrm{I}^{-}$, and $\mathrm{SCN}^{-}$which result in the sharp peaks in the high temperature range of the DSC curve, while the second group of anions are $\mathrm{PO}_{4}{ }^{3-}, \mathrm{BO}_{3}{ }^{3-}, \mathrm{CH}_{3} \mathrm{COO}^{-}, \mathrm{NO}_{3}{ }^{-}, \mathrm{ClO}_{4}{ }^{-}, \mathrm{SO}_{4}{ }^{2-}, \mathrm{IO}_{3}{ }^{-}, \mathrm{F}^{-}$which cause those peaks to decrease and broaden. The first group belongs to non-oxoacid and the second group except for $\mathrm{F}^{-}$belongs to oxoacids.

According to HSAB (Hard and Soft Acids and Bases) rule proposed by Pearson (11-13) for the nucleophilic reaction of Lewis acids and bases, $\mathrm{I}^{-}$and $\mathrm{SCN}^{-}$classified above into the first group belong to soft bases (which is polarizable, low in electronegativity, and oxidizable) and $\mathrm{F}^{-}, \mathrm{CH}_{3} \mathrm{COO}^{-}, \mathrm{PO}_{4}{ }^{3-}, \mathrm{SO}_{4}{ }^{2-}, \mathrm{ClO}_{4}{ }^{-}$, and $\mathrm{NO}_{3}{ }^{-}$classified above into the second group belong to hard bases (which is nonpolarizable, high in electronegativity, and reducible). With $\mathrm{Br}^{-}$and $\mathrm{Cl}$ classified into the first group, the former belongs to an intermediate base between hard and soft bases, and the latter is much weaker in hardness than $\mathrm{F}^{-}$, although it belongs to a hard base.

Thus the effect of anions on the DNA melting mentioned above seems to be 
closely related to hardness or softness of bases based on HSAB rule. Since hard acids bind strongly to hard bases and soft acids bind strongly to soft bases according to HSAB rule, $\mathrm{F}^{-}$and other oxoacids (except for $\mathrm{BO}_{3}{ }^{3-}$ ) classified as hard bases will strongly interact with water which also belongs to a hard acid when it is considered as acid (11), and may result in the alteration of the structure of water. On the other hand. halide ions other than $\mathrm{F}^{-}$and $\mathrm{SCN}^{-}$which belong to soft bases will interact with water to a lesser degree, resulting in less or no change of the structure of water. Thus, the variation of DNA melting in the presence of the anions is likely to be closely related to change in the state of water around DNA molecules caused by anion-water interaction.

It is not clear at present whether or not the less hysteresis of DNA melting observed in the borate buffers is related to HSAB rule. The less hysteresis of DNA melting is of interest in connection with the annealing experiment of DNA for which the borate buffers may be recommended as annealing buffers. The detailed study is necessary to know the mechanisms of the reversibility of DNA melting.

\section{REFERENCES}

1) Dove, W. F. and Davidson, N., Cation effects on the denaturation of DNA. J. Mol. Biol., 5, 467478 (1962).

2) Hamaguchi, K. and Geiduschek, E. P., The effect of electrolytes on the stability of the deoxyribonucleate helix. J. Am. Chem. Soc., 84, 1329-1338 (1962).

3) Hartman, K. A., Jr., The structure of water and the stability of the secondary structure in biological molecules. An infrared and proton magnetic resonance study. J. Phys. Chem., 70, 270276 (1966).

4) Keller, P. B., Loprete, D. M., and Hartman, K. A., Structural forms and transitions of poly(dG-dC) with Cd(II), Ag(I) and $\mathrm{NaNO}_{3}$. J. Biomol. Struct. Dyn., 5, 1221-1229 (1988).

5) Maeda. Y., Kawai, Y., Fujita, T., and Ohtsubo, E., Differential scanning calorimetric study of plasmid DNA. J. Gen. Appl. Microbiol., 30, 289-295 (1984).

6) Maeda, Y., Nunomura, K., and Ohtsubo, E., Differential scanning calorimetric study of the effect of intercalators and other kinds of DNA-binding drugs on the stepwise melting of plasmid DNA. J. Mol. Biol., 215, 321-329 (1990).

7) Maeda, Y., Nunomura, K., and Ohtsubo, E., Interaction of an anthracycline antibiotic, 4'$O$-tetrahydropyranyl-adriamycin (pyrarubicin), with plasmid pJL3-TB5 DNA. Thermochim. Acta, 163, 129-132 (1990).

8) Maeda, Y. and Ohtsubo, E., Relationship between helix-coil transition and gene organization of ColE1 DNA: Differential scanning calorimetric and theoretical study. J. Mol. Biol., 194, 691-698 (1987).

9) McDonnel, N. B. and Preisler, R. S., Hydrophobic moieties in cations, anions, and alcohols promote the B-to-Z transition in poly $[\mathrm{d}(\mathrm{G}-\mathrm{C})]$ and poly $\left[\mathrm{d}\left(\mathrm{G}-\mathrm{m}^{5} \mathrm{C}\right)\right]$. Biochem. Biophys. Res. Commun., 164, 426-433 (1989).

10) Ohtsubo, E., Rosenbloom, M., Schrempf, H., Goebel, W., and Rosen, J., Site specific recombination involved in the generation of small plasmid. Mol. Gen. Genet., 159, 131-141 (1978).

11) Pearson, R. G., Hard and soft acids and bases. J. Am. Chem. Soc., 85, 3533-3539 (1963).

12) Pearson, R. G., Acids and bases. Science, 151, 172-176 (1966).

13) Pearson, R. G., Hard and soft acids and bases, HSAB, Part I. J. Chem. Educ., 45, 581-587 (1968). 
14) Robinson, D. R. and Grant, M. E., The effects of aqueous salt solutions on the activity coefficients of purine and pyrimidine bases and their relation to the denaturation of deoxyribonucleic acid by salts. J. Biol. Chem., 241, 4030-4042 (1966).

15) Wada, A., Yabuki, S., and Husimi, Y., Fine structure in the thermal denaturation of DNA: High temperature-resolution spectrophotometric studies. CRC Crit. Rev. Biochem., 9, 87-144 (1980).

16) Yamaki, H., Ohtsubo, E., Nagai, K., and Maeda, Y., The oriC unwinding by dam methylation in Escherichia coli. Nucl. Acids Res., 16, 5067-5073 (1988). 